\title{
The Boomerang of Female40: seniority pensions in Hungary, 2011-2018
}

ANDRÁS SIMONOVITS 


$$
\begin{aligned}
& \text { Discussion papers } \\
& \text { MT-DP - 2018/32 }
\end{aligned}
$$

Institute of Economics, Centre for Economic and Regional Studies, Hungarian Academy of Sciences

KTI/IE Discussion Papers are circulated to promote discussion and provoque comments. Any references to discussion papers should clearly state that the paper is preliminary. Materials published in this series may subject to further publication.

The Boomerang of Female40: seniority pensions in Hungary, 2011-2018

Author:

András Simonovits research advisor Institute of Economics

Centre for Economic and Regional Studies, Hungarian Academy of Sciences also Mathematical Institute of Budapest University of Technology

E-mail: simonovits.andras@krtk.mta.hu

December 2018 


\title{
The Boomerang of Female40: seniority pensions \\ in Hungary, 2011-2018
}

\author{
András Simonovits
}

\begin{abstract}
In 2011, the Hungarian government introduced seniority pensions (Female40): females, who have been accumulating at least 40 years of eligibility (related to the length of contributions), can retire at any age without actuarial benefit reduction. The elimination of other early retirement scheme in 2012 and slowly rising real wages made the program even more popular: the lifetime benefit was maximized at the earliest retirement. Since 2016, real wages have been growing rather fast; making delay attractive. Without being recognized, Female40 has become a boomerang: immediate retirement from 2014 causes loss rather than gain to the retiree of Female40.
\end{abstract}

Keywords: public pension, early retirement, seniority pensions, optimal retirement age

JEL-code: H55

Acknowledgement: I am indebted to N. Barr for his suggestions on an earlier version. 


\title{
A Nők40 bumerángja: szenioritási nyugdíjak Magyarországon, 2011-2018
}

\author{
Simonovits András
}

\section{Összefoglaló}

2011-ben a magyar kormány bevezette a Nők40-nek nevezett szenioritási nyugdíjat nyugdíjba mehettek azok a nők, akik legalább 40 éves jogviszonyt összegyüjtöttek az általános nyugdíjkorhatár elérése előtt, bárminemű biztosításmatematikai nyugdíjcsökkentés nélkül. E rendszer népszerüségét tovább növelte, hogy 2012-től kezdve megszűnt minden más előrehozott nyugdíjba vonulási lehetőség: a lassan emelkedő reálbérek mellett a továbbdolgozás olyan kevéssé emelte az éves nyugdíjat, hogy az életpályanyugdíj csökkent. 2016-tól kezdve a reálbérek átlaga nagyon gyorsan nő, vonzóvá téve a továbbdolgozást. Ha ezt nem ismerik fel, akkor a Nők4o bumeránggá változik, az azonnali nyugdíjba vonulás nyereségből veszteséggé változik.

Tárgyszavak: társadalombiztosítási nyugdíj, előrehozott nyugdíj, szenioritási nyugdíjak, optimális nyugdíjba vonulási kor

JEL: H55 


\title{
The Boomerang of Female40: Seniority Pensions in Hungary, 2011-2018*
}

\author{
by András Simonovits \\ Research Center for Economics and Regional Sciences, HAS \\ Email: simonovits.andras@krtk.mta.hu,
}

\begin{abstract}
In 2011, the Hungarian government introduced seniority pensions (Female40): females, who have been accumulating at least 40 years of eligibility (related to the length of contributions), can retire at any age without actuarial benefit reduction. The elimination of other early retirement scheme in 2012 and slowly rising real wages made the program even more popular: the lifetime benefit was maximized at the earliest retirement. Since 2016, real wages have been growing rather fast; making delay attractive. Without being recognized, Female40 has become a boomerang: immediate retirement from 2014 causes loss rather than gain to the retiree of Female40.
\end{abstract}

JEL: H55

Keywords: public pension, early retirement, seniority pensions, optimal retirement age

\footnotetext{
${ }^{*}$ I am indebted to N. Barr for his suggestions on an earlier version.
} 


\section{Introduction}

In this paper, I consider a Hungarian early retirement scheme what I call Female40. This scheme allows any female who had accumulated 40 years of eligibility (related to but not identical to 40 years of contributions) to retire before reaching the full benefit retirement age without suffering any actuarial deduction. (All other early retirement schemes are closed down.) I show that if the real wage growth is slow, then Female40 is advantageous to its participants but it becomes a boomerang with fast real wage growth, occurring from 2016. I presume that this result may have relevance for other seniority retirement systems as well.

With the spectacular rise of Social Security in the 1970s, early retirement has become a norm (Burtless, 1986). In contrast, during the last decades, the average retirement age has been growing all over the world. In addition to rising full retirement age, the incentives of delayed retirement and the disincentives for early retirement have generally become stronger (e.g. Gruber, eds. 2004). The system called Notional Defined Contribution (NDC) has even eliminated full retirement age as unnecessary. As a trend, exemptions for females have also been phased-out; for example, the gap between full male and female retirement ages and the special exemptions have generally been reduced or eliminated. These trends have generally been followed in the ex-communist countries, too (cf. Domonkos and Simonovits, 2016).

As a reaction, several governments tried to lighten the burden of higher retirement age. Populist governments decreased full retirement age in France, Italy and Poland. From the point of view of the present paper, however, the German reform in 2014 is the most pertinent: the full retirement age of 65 growing to 67 years was reduced to 63, conditional on 45 years of contributions - a type of seniority pensions. While the German government claims it is a deserved measure, its critics evaluate it as undeserved (cf. Laub, 2018).

These trends have also characterized Hungary. The full retirement age rose from 55/60 in 1995 to $62 / 62$ by 2009; a significant further rise was enacted in 2009, ending with 65 by 2022 . The strengthened disincentives made early retirement even more costly, and the new system of 2009 resembled an actuarial fair system (NDC). In the latter, the new benefit is the ratio of the lifetime contribution divided by the expected remaining life expectancy. As already said above, But in 2011, the new government introduced Female40: those females who obtained at 
least 40 years of eligibility can retire much before reaching the full retirement age without suffering any actuarial benefit reduction. (Note that the eligibility period does not contain years spent in vocal schools or at higher education. While the benefit is proportional to the former, the Female40 depends on the latter. In Table 2, the former is above 40 on average.) The Female40's popularity has been further enhanced by the elimination of any other channel of early retirement since 2012. At least half the new female retirees chose it (Tables 1 and 2 below). Under moderate real wage growth (see Table 4 below), this reform made the lifetime benefit a decreasing function of the retirement age from the start, and put its maximum at the implicit minimal retirement age defined by the sum of the entry-to-labor age +40 , i.e. cc. $55-$ 60 years.

Czeglédi, Simonovits, Szabó and Tir (2017) critically analyzed the Hungarian retirement rules, and widely documented the problems of Female40. One form of the inequities is the strongly negative correlation between the retirement age and the length of contribution. Granseth, Keck, Nagl, Simonovits and Tir (2019) also studied the correlation coefficient in an international framework.

The proponents of Female40 have hardly mentioned that such a system is very unfair to those workers (males or females) who are close to the full retirement age and-due to the fragmented labor careers - have a little shorter length of eligibility. To make the point, compare two women having unit net wages during all their careers. In 2016, $A$ was of age 60, worked 40 years and expectedly will live another 19 years; and $C$ was of age 63, worked for 39 years and - neglecting death between 60 and 63 - had 16 years of remaining life expectancy. Calculating with a marginal accrual rate of $2 \% / y e a r$, and an actuarial reduction of 6\%/year, we have the following result: $A$ 's and $C$ 's annual benefits would be $(1-3 \times 0.06) \times 0.02 \times 40=0.656$ and $0.02 \times 0.39=0.78$, respectively. Furthermore, the corresponding lifetime benefits of $A$ and $C$ would be the same, namely $19 x 0.656=12.5$ $=16 \times 0.78$ units. In contrast, Female40 raises $A$ 's benefit from 0.656 to 0.8 , and her lifetime benefit from 12.5 to $19 \times 0.8=15.2$ units.

Since 2016, the real value of the average Hungarian net wages has been growing very fast (Table 4), lifting the real value of the average new pensions in parallel with a one-year lag. The unemployment rate has drastically fallen, making older-age employment easier. Therefore one would expect that more and more eligible women continued working beyond 
the earliest retirement age, say 55-60 years. Returning to $A$, recall that she retired in 2016 just having the 40 years of contributions and of eligibility. If she continued working until 2019, however, her wage would grow by $28 \%$, her total accrual rate would rise from 80 to $86 \%$, therefore her annual pension would be multiplied by $1.28 \times 1.075=1.376$ i.e. it grew to 1.104 units, all in real terms. Though she would enjoy this elevated pension only for 16 years, her lifetime pension wealth would still rise to 17.7 units, by $16.2 \%$ with respect to the immediate 15.2 units.

Not only our ordinary female worker but even the bulk of the Hungarian experts has not realized this boomerang effect of Female40; or if they have realized, they have kept their secret for themselves. Unfortunately, the scanty official data on Female40 (Tables 1-3 below) precludes any sensible estimation of the percentage of women who avoided the boomerang effect by delaying their retirement.

In Section 2, I present the basic numbers on the characteristics of female retirement in between 2011 and 2016 and on the real wage growth between 2010 and 2021,. In Section 3, I discuss the optimal retirement age of farsighted females without taking into account the additional measures like overindexation of pensions between 2013 and 2016 and the ad hoc additional benefits in 2017 and 2018. Section 4 extends the analysis to these additional measures. Section 5 replaces the farsighted worker with a naïve one, who only forecasts real wages by one-year ahead. Section 6 discusses the findings and draws the conclusions.

\section{Basic data}

Since 2009, in Hungary the rise of full retirement age can be described as follows: 62 (20092013), 63 (2016), 64 (2019) and 65 (2022). Between these years, the full retirement age rose and will rise by $1 / 2$ year for those who were born in Spring and Fall in the transition years, respectively.

Table 1 presents the mean retirement age and number of newly retired Hungarian females: all and Female40, respectively. Note that the share of Female40 has been quite high and the gap between the general and the special mean retirement ages has been rising to 2 years. 
Table 1. The characteristics of new female retirees, Hungary, 2011-2016

\begin{tabular}{|c|c|c|c|c|}
\hline Years & \multicolumn{2}{|c|}{ All } & \multicolumn{2}{c|}{ Female40 } \\
\hline & $\begin{array}{c}\text { Mean }{ }^{\text {a }} \text { retirement } \\
\text { age }\end{array}$ & Number, in 000 & $\begin{array}{c}\text { Mean }{ }^{\text {a }} \text { retirement } \\
\text { age }\end{array}$ & Number, in 000 \\
\hline 2011 & 58.5 & 85.0 & 57.6 & 54.8 \\
\hline 2012 & 59.2 & 51.2 & 57.8 & 26.6 \\
\hline 2013 & 59.6 & 40.2 & 58.0 & 24.1 \\
\hline 2014 & 59.6 & 39.1 & 58.3 & 27.6 \\
\hline 2015 & 60.0 & 41.6 & 58.7 & 28.6 \\
\hline 2016 & 61.0 & 55.0 & 59.0 & 29.0 \\
\hline $2017^{\mathrm{b}}$ & 60.9 & 45.5 & 59.3 & 28.4 \\
\hline
\end{tabular}

Source. Fazekas and Köllö, eds. (2017), Table 11.5, p. 269. a) We replaced the original, adjective median and b) the data of 2017 are taken from other sources.

Table 2 presents the distribution of age and length of contribution of women retiring in Female 40 in 2013 . Note that only $56 \%$ of the new Female 40 retirees had just 40 years of contribution but the data do not tell us the years of eligibility.

Table 2. Data of Female40, 2013

\begin{tabular}{|c|c|c|c|c|c|c|c|c|}
\hline \multirow[t]{2}{*}{$\begin{array}{l}\text { Birth } \\
\text { year }\end{array}$} & \multirow{2}{*}{$\begin{array}{l}\text { Size } \\
\text { distri- } \\
\text { bution, } \\
\%\end{array}$} & \multirow{2}{*}{$\begin{array}{l}\text { Average } \\
\text { reti- } \\
\text { rement } \\
\text { age }\end{array}$} & \multirow{2}{*}{$\begin{array}{l}\text { Average } \\
\text { length } \\
\text { of } \\
\text { contri- } \\
\text { bution }\end{array}$} & \multicolumn{5}{|c|}{$\begin{array}{l}\text { Size distribution according to contribution length } \\
\%\end{array}$} \\
\hline & & & & 40 & 41 & 42 & 43 & 44 \\
\hline 1953 & 4.9 & 60.0 & 41.5 & 37.7 & 29.4 & 18.4 & 4.9 & 5.1 \\
\hline 1954 & 26.6 & 59.0 & 41.1 & 59.7 & 16.1 & 8.5 & 8.5 & 4.4 \\
\hline 1955 & 32.9 & 58.2 & 41.1 & 61.4 & 9.3 & 15.2 & 10.5 & 1.7 \\
\hline 1956 & 17.7 & 57.1 & 41.7 & 31.2 & 17.4 & 37.8 & 11.3 & 0.0 \\
\hline 1957 & 9.3 & 56.1 & 40.7 & 65.6 & 23.6 & 7.2 & 0.0 & $*$ \\
\hline 1958 & 4.7 & 55.2 & 40.3 & 87.1 & 9.7 & * & * & * \\
\hline Average & 100.0 & 57.9 & 41.1 & 56.3 & 14.8 & 15.9 & 8.2 & 2.0 \\
\hline
\end{tabular}

Source: ONYF $(2014,111-112$, Table 6.9)

Table 3 displays the distribution of the length of contribution and age at retirement of newly retired Hungarian females in 2016. (Note the divergence between these numbers and those of Table 1!) While the average length of contribution was 37.8 years, $35.5 \%$ of women retired within Female 40 and another $8.9 \%$ at the borderline of age 63 . 
Table 3. Distribution of newly retired Hungarian females, 2016

\begin{tabular}{|l|l|l|l|}
\hline $\begin{array}{c}\text { Retirement age } \\
\text { Length of contribution }\end{array}$ & Early: $58.6 \mathrm{yr}$ & Full: $63 \mathrm{yr}$ & Average: $60.6 \mathrm{yr}$ \\
\hline Short: $31.4 \mathrm{yr}$ & 0 & 0.551 & 0.551 \\
\hline Sufficient: $41.2 \mathrm{yr}$ & 0.355 & 0.089 & 0.449 \\
\hline Average: $37.8 \mathrm{yr}$ & 0.355 & 0.640 & 1.000 \\
\hline
\end{tabular}

Source: Calculated from a detailed table supplied by the Hungarian Treasury on public request.

Average real wage changes are given in Table 4, where * refers to my forecasts with decelerating real net wage dynamics.

Table 4. Time series of average real wage: $2010=100$

\begin{tabular}{|c|c|c|c|}
\hline Year & Net wage & Year & Net wage \\
\hline 2010 & 100,0 & 2016 & 117,9 \\
\hline 2011 & 102,4 & 2017 & 129,9 \\
\hline 2012 & 98,9 & 2018 & 140,3 \\
\hline 2013 & 102,0 & 2019 & $148,7^{*}$ \\
\hline 2014 & 105,2 & 2020 & $154,7^{*}$ \\
\hline 2015 & 109,8 & 2021 & $160,9^{*}$ \\
\hline
\end{tabular}

Source: Central Statistical Office and my own forecast

\section{Farsighted females - no additional measures}

In this Section, we consider the choice of retirement age by farsighted females in Female 40 delaying the consideration of the impact of additional measures to Section 4. Let $t$ be the index of calendar year, and $v_{t}$ be the average net wage of that year. Our heroine always earned the average wage and by year $t$, she just accumulated $S=40$ years of contribution and eligibility. Her age (say 59) was well below the then current full retirement age, therefore even if she delayed her retirement by $s$ years, she could not obtain delayed retirement credit, her benefit just grew from $b_{0, t}=\delta S v_{t-1}$ to $b_{s, t}=\delta(S+s) v_{t+s-1}, \delta$ is the marginal accrual rate. (In the other case, the delay is much more profitable.) There are a number of possible objective functions what the retiree could consider but we choose the simplest one, the lifetime pension benefit in real terms: $B_{s . t}=(T-s) b_{s, t}=(T-S) \delta(S+s) v_{t+s-1}$.

Note that if one neglects the change in the real wage $v_{t+s-1}$, then the simplified objective function $B_{s . t}=(T-S) \delta(S+s) v$ attains its unconstrained maximum at $s^{*}=(T-S) / 2<0$ for 
practical values of $S$ and $T$. But in reality, there is an implicit minimum retirement age $R_{m}$ $=Q+S$, where $Q$ is the entry age to work, $Q \geq 15$ years. Obviously, $Q+S+s^{0}<R_{m}$, therefore the constrained maximum is attained at $s^{\mathrm{o}}=R_{m}-S-Q$. If one takes into account the persistent changes in $v_{t+s-1}$, then finding the constrained maximum is not trivial.

For convenience, we replace the earliest retirement age from 60 to 59 and assume that those spend another $T=20$ years in retirement. Substituting the data of Table 1 into our formulas, we obtain Table 5. Columns 1 and 2 show the calendar time $(t)$ and the delay $(s)$, respectively. Columns 3 and 4 respectively display the annual and the lifetime benefits (the latter, for a farsighted worker, who knows the real wage dynamics in advance for three years.) For example, in the row $(2012,1), 0.811$ and 15.4 units show the new and the lifetime benefits for a woman, respectively, who retired in 2013 with 41 years of contributions. (Column 5 will be explained in Section 4.) The maximal values are italicized. For example, those who could retire in 2011 and 2012 in Female40 and retired immediately $\left(s_{t}{ }^{\circ}=0\right)$, chose optimally, while from 2013, the optimal decision was maximal delay $\left(s_{t}{ }^{0}=3\right)$. (Note that we obtained numerically different results here than in the example in the Introduction, because here we calculate with net wage $v_{2016}=1.179$, while we had unit net wage there.) 
Table 5. Optimal delay of retirement in Female 40 (pure and mixed)

\begin{tabular}{|c|c|c|c|c|}
\hline \multirow[t]{2}{*}{ Year } & \multirow[t]{2}{*}{ Delay } & \multirow[t]{2}{*}{ Annual benefit } & Pure & Mixed \\
\hline & & & \multicolumn{2}{|c|}{ Lifetime benefit } \\
\hline$t$ & $S$ & $b_{s . t}$ & $B_{s . t}$ & $\boldsymbol{B}_{s . t}$ \\
\hline \multirow[t]{4}{*}{2011} & 0 & 0.800 & 16.0 & 19.4 \\
\hline & 1 & 0.840 & 16.0 & 19.5 \\
\hline & 2 & 0.831 & 15.0 & 17.9 \\
\hline & 3 & 0.877 & 14.9 & 17.5 \\
\hline \multirow{4}{*}{2012} & 0 & 0.819 & 16.4 & 20.1 \\
\hline & 1 & 0.811 & 15.4 & 18.5 \\
\hline & 2 & 0.857 & 15.4 & 18.2 \\
\hline & 3 & 0.905 & 15.4 & 17.9 \\
\hline \multirow{4}{*}{2013} & 0 & 0.791 & 15.8 & 19.1 \\
\hline & 1 & 0.836 & 15.9 & 18.9 \\
\hline & 2 & 0.884 & 15.9 & 18.6 \\
\hline & 3 & 0.944 & 16.1 & 18.5 \\
\hline \multirow{4}{*}{2014} & 0 & 0.816 & 16.3 & 18.5 \\
\hline & 1 & 0.863 & 16.4 & 19.3 \\
\hline & 2 & 0.922 & 16.6 & 19.2 \\
\hline & 3 & 1.014 & 17.2 & 19.8 \\
\hline \multirow[t]{4}{*}{2015} & 0 & 0.842 & 16.8 & 19.9 \\
\hline & 1 & 0.900 & 17.1 & 19.9 \\
\hline & 2 & 0.990 & 17.8 & 20.5 \\
\hline & 3 & 1.117 & 19.0 & 21.6 \\
\hline \multirow[t]{4}{*}{2016} & 0 & 0.878 & 17.5 & 20.5 \\
\hline & 1 & 0.967 & 18.4 & 21.2 \\
\hline & 2 & 1.091 & 19.6 & 22.4 \\
\hline & 3 & 1.207 & 20.5 & 23.2 \\
\hline \multirow[t]{4}{*}{2017} & 0 & 0.943 & 18.9 & 21.9 \\
\hline & 1 & 1.065 & 20.2 & 23.2 \\
\hline & 2 & 1.179 & 21.2 & 24.1 \\
\hline & 3 & 1.279 & 21.7 & 24.6 \\
\hline \multirow[t]{4}{*}{2018} & 0 & 1.039 & 20.8 & 23.9 \\
\hline & 1 & 1.151 & 21.9 & 24.9 \\
\hline & 2 & 1.249 & 22.5 & 25.4 \\
\hline & 3 & 1.330 & 22.6 & 25.5 \\
\hline
\end{tabular}

\section{Additional benefit measures}

The Hungarian pension policy has very rarely followed the main rules (for details, Ádám and Simonovits, 2018). For example, between 2013 and 2016, the inflationary forecasts were significantly higher than the actual inflation rates: their difference (or more precisely: the ratio of the forecasted inflation coefficient to the actual one-1) were as follows: $3.4 \%$ (2013), $2.6 \%$ 
(2014), 1.9\% (2015) and 1.9\% (2016). The actual benefits in progress rose in real terms the same way, this I call overindexation of benefits, and these raises formed the proportional basis of further benefit raises $\left(k_{t+s+u}\right)$. In addition, in 2017 and 2018, the government applied the Pension Plus (enacted by a previous government in 2010 as a symbolic replacement of the earlier $13^{\text {th }}$ month benefit) and a modest extra benefit called Elisabeth voucher (named after a benevolent Hungarian princess of the $13^{\text {th }}$ century). These extra benefits $\left(m_{t+s+u}\right)$ have been more or less flat, and amounted to cc. $1-2 \%$ of the average pension. In our new calculations, we assume that there will not be such surprise raises except for the Elisabeth voucher of $1 \%$ of annual average benefit. We shall now calculate with these extended benefits and the corresponding objective functions:

$b_{s, t, 0}=\delta(S+s) v_{t+s-1}, b_{s, t, u}=b_{s, t, u-1} k_{t+s+u}+m_{t+s+u}$ and $\boldsymbol{B}_{s . t}=\boldsymbol{\Sigma}_{u} b_{s, t, u}$.

All these additions may have modified the optimal delay. Indeed, as Column 5 of Table 5 demonstrates, in 2011, the 1-year rather than the 0-year delay would have been optimal, while in 2013, the 0-year rather than the 3-year delay would have been optimal. In other years, these additions have not modified the optimal delay.

\section{Naïve worker}

Until now, we have not only assumed that our heroines understood the system perfectly; but also that they had a perfect foresight. Now we replace the second assumption with a weaker one: at the end of year $t+s$, when they decide (possibly not at the first occasion) on their retirement, they do know not only the current average wage but also the next year's value. And they always consider delaying retirement just by 1 year. In our example, this bounded prevision is enough, they always choose the same delay as if they had unbounded prevision. But in other cases, this is generally not true.

\section{Discussion and conclusions}

In this paper, we have studied a special Hungarian seniority pension scheme, Female40, which rewards any female with a full benefit (without actuarial deduction) even if she has not reached the full retirement age but accumulated at least 40 years of eligibility. We have analyzed three related models: 1) the basic model, where the heroine knows the real wage 
dynamics in advance but excludes additional measures; 2) the extended model, where the heroine knows the real wage dynamics and the additional measures in advance; 3 ) the naïve heroine who only forecasts and considers the average real wage one year ahead and neglects the extended benefits. In models 1 and 3, the optimal delay of retirement is the same in all the eight years; while in the extended model, the additional measures modify the optimal retirement age in years 2011 and 2013.

For simplicity, we have neglected a number of complicating technical factors: (i) We have chosen the simplest objective function, namely the lifetime benefit; we have not even discounted it, not speaking about replacing it with a traditional lifetime utility function. (ii) We have not distinguished the length of contributions and the of the eligibility period. (iii) We have neglected the fine structure of years consisting of 12 months, the more so because even the $11^{\text {th }}$ month of the last year of contribution is neglected in the Hungarian benefit calculations. (iv) We have not discussed the lifetime balance of contributions and benefits either (see Granseth et al., 2019, Appendix B without real wage rise). (v) Our model is especially relevant if our heroines can work after retiring until reaching the full retirement age.

In this paper, we have assumed that the heroines of type $A$, close to retirement in $2011, \ldots$, 2018 , or at least their advisers understood the pension rules, especially the impact of real wages on the benefits. This assumption is very far from reality, and its neglect leads to unconditional early retirement in the framework of Female40. Suppose that this decision appears to be optimal, but having retired, our heroines exchange experiences with similar retirees younger by 1, 2 or 3 years. Then the older retirees may realize that the government's scheme was a boomerang: it would have been better to retire later and enjoy the much higher annual benefits for a little shorter period.

I do not claim that the Hungarian government intentionally has misled a large part of the new female retirees (cf. Ádám and Simonovits, 2018). Probably its experts have not made the calculations outlined here or if they did, then they dared not share them with their bosses. The parties of opposition have also remained silent or some of them even demanded the extension of Female40 to Male40. But apart from good or bad intentions, a lot of Hungarian citizens lost, and this could have been avoided with more wisdom, honesty and openness. 


\section{References}

Ádám, Z. and Simonovits, A. (2018): "From Democratic to Authoritarian Populism:

Comparing pre- and post-2010 Hungarian Pension Policies", Acta Oeconomica 68, to appear.

Burtless, G. (1986): "Social Security, Unanticipated Benefit Increases and the Timing of Retirement," Review of Economic Studies, 53, 781-805.

Czeglédi, T.; Simonovits, A.; Szabó, E. and Tir, M. (2017): "What is Wrong with the Hungarian Pension Rules?” Acta Oeconomica, 67, 359-387.

Domonkos, S. and Simonovits, A. (2017): "Pension Reforms in EU11 Countries: An Evaluation of Post-socialist Pension Policies”, International Social Security Review, $70,109-128$.

Fazekas, K. and Köllő, J. eds. (2017): The Hungarian Labor Market 2017, Budapest, CERS Institute of Economics.

Granseth, E.; Keck, W.; Nagl, W.; Simonovits, A. and Tir, M. (2019): "Negative Correlation between Retirement Age and Contribution Length?" Oxford Economic Papers, to appear.

Gruber, J. eds. (2004): Social Security Programs and Retirement around the World, Microestimation. NBER Conference Report, Chicago, Chicago University Press..

Laub, N. (2018): "Reduced Retirement Age - Off we Go!?” lecture at the Conference of the International Institute of Public Finance, Tampere.

ONYF (2014): ONYF Statistical Yearbook, 2013 (in Hungarian) Budapest, CANPI 